Diunggah : Januari 2021

Diterima : Mei 2021

Dipublikasi : Juni 2021

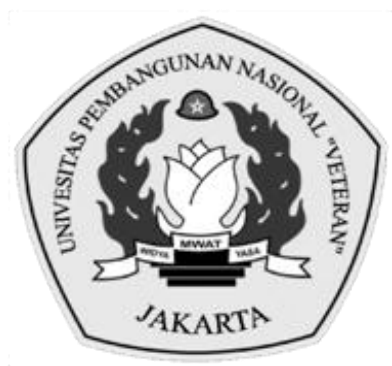

\title{
ANALISIS PENGARUH ROTASI AUDITOR, AUDIT TENURE DAN REPUTASI KAP TERHADAP KUALITAS AUDIT
}

\author{
Retna Sari ${ }^{*}$, Mira Rahmi ${ }^{2}$ \\ 1retnasari@upnvj.ac.id, ${ }^{2}$ mirarahmi@upnvj.ac.id \\ 1,2Universitas Pembangunan Nasional Veteran Jakarta, Indonesia \\ *Penulis Korespondensi
}

\begin{abstract}
Abstrak
Kualitas audit di Indonesia pada saat ini sedang mengalami penurunan dengan munculnya beberapa kasus gagal audit dalam beberapa laporan keuangan untuk perusahaan yang listing di Bursa Efek Indonesia (BEI). Kasus gagal audit yang muncul terlebih dilakukan oleh beberapa Kantor Akuntan Publik (KAP) 4 besar (big four) di Dunia. Penelitian ini bertujuan untuk mengetahui pengaruh rotasi auditor, audit tenure, dan reputasi KAP terhadap kualitas audit. Sampel dalam penelitian ini adalah perusahaan manufaktur sektor barang konsumsi yang terdaftar di Bursa Efek Indonesia tahun 2016 - 2018 yaitu sebanyak 189 perusahaan yang terpilih menjadi sampel dengan menggunakan teknik purposive sampling. Teknik analisis data yang digunakan dalam penelitian ini adalah Regresi Logistik dengan tingkat signifikansi sebesar 5\%. Hasil pengujian hipotesis menunjukkan bahwa rotasi auditor berpengaruh negatif terhadap kualitas audit, reputasi KAP berpengaruh positif terhadap kualitas audit, sedangkan audit tenure tidak berpengaruh terhadap kualitas audit.
\end{abstract}

Kata Kunci: Kualitas Audit; Rotasi Auditor; Audit Tenure; Reputasi KAP.

\begin{abstract}
The quality of audits in Indonesia is currently declining with the emergence of several cases of failed audits in several financial statements for companies listed on the Indonesia Stock Exchange (IDX).The case failed an audit that appeared first conducted by several Public Accounting Firms (KAP) 4 large (big four) in the World.This study aims to determine the influence of auditor rotation, tenure audit, and KAP reputation on audit quality.The samples in this study were consumer goods sector manufacturing companies listed on the Indonesia Stock Exchange in 2016 - 2018, namely as many as 189 companies selected to be sampled using purposive sampling techniques. Data analysis techniques used in this study are logistic regression with a significance rate of 5\%. Hypothetical test results show that auditor rotation negatively affects audit quality, KAP reputation positively affects audit quality, while tenure audit has no effect on audit quality.
\end{abstract}

Keywords: Quality Audit; Auditor Rotation; Audit Tenure; Public Accounting Firm Reputation.

\section{PENDAHULUAN}

Laporan keuangan menjadi suatu sumber informasi penting yang dihasilkan oleh suatu perusahaan dan dapat memberikan pengaruh atas pengambilan keputusan para investor. Laporan keuangan yang berkualitas akan menggambarkan manajemen perusahaan yang taat dan patuh terhadap regulasi 
yang berlaku yaitu Standar Akuntansi Keuangan (SAK) sehingga mampu menumbuhkan rasa percaya yang tinggi dari para pengguna maupun masyarakat umum. Kualitas sebuah laporan keuangan dapat dinilai melalui proses audit. Hasil audit atau opini dalam laporan keuangan merupakan suatu tolak ukur yang dapat dijadikan penilaian oleh manajemen perusahaan maupun para pengguna laporan keuangan. Hasil audit tersebut sangat didukung oleh jasa tim audit dari Kantor Akuntan Publik (KAP) yang dinilai independen dalam menerbitkan hasil opininya. Akuntan publik dapat dikatakan sebagai penyedia jasa assurance, yang merupakan jasa secara profesional dan independen serta bertanggung jawab untuk meningkatkan relevansi informasi, kualitas, dan keandalan untuk pengambilan keputusan (Arens, 2014; Tuanakotta, 2015).

Tujuan dari keseluruhan auditor dalam menjalankan audit laporan keuangan yaitu untuk mendapat rasa yakin yang cukup atas laporan keuangan seluruhnya terbebas dari kesalahan saji yang material, baik yang diakibatkan karena kesalahan atau kecurangan, dan maka sebab itu memungkinkan auditor dalam menyatakan suatu opini terkait apakah laporan keuangan disajikan, mencakup segala bentuk yang bersifat material, sesuai yang telah ditetapkan dalam kerangka pelaporan keuangan (SA 200 (11) poin a). Kualitas jasa audit di Indonesia pada saat ini dinilai sedang mengalami penurunan dengan munculnya beberapa kasus gagal audit dalam beberapa laporan keuangan untuk perusahaan yang listing di BEI. Salah satu kasus gagal audit ternyata juga dilakukan oleh beberapa KAP ternama di Indonesia.

Kasus audit di Indonesia terjadi pada salah satu KAP yaitu KAP Amir Abadi Jusuf, Aryanto, Mawar dan Rekan berafiliasi dengan RSM International. KAP ini telah mengaudit laporan keuangan perusahaan manufaktur bernama PT Tiga Pilar Sejahtera Food Tbk (AISA) selama beberapa tahun yaitu sejak tahun 2004 hingga 2017. Kasus ini bermula pada saat investor tidak mau menerima laporan keuangan audit periode 2017 dengan tuduhan adanya kesalahan pengelolaan dana oleh pihak manajemen lama. Kemudian masuk pada bulan Oktober 2018, diadakanlah Rapat Umum Pemegang Saham Luar Biasa (RUPSLB) yang resmi membentuk jajaran komisaris baru dan melakukan pergantian direksi. Berdasarkan hasil investigasi, ditemukan bahwa ada dugaan pencatatan yang overstatement pada pos persediaan, piutang usaha serta aset tetap dari grup AISA sejumlah Rp 4 triliun. Kemudian, ditemukan juga dugaan penggelembungan pendapatan senilai Rp 662 Miliar serta penggelembungan pada pos EBITDA (depresiasi, laba sebelum bunga, amortisasi, dan pajak) sebesar Rp 392 Miliar. KAP Amir Abadi Jusuf, Aryanto, Mawar dan Rekan diperkirakan tidak mampu mendeteksi kesalahan laporan keuangan di PT. AISA pada tahun 2017 sehingga publik menganggap bahwa KAP tersebut tidak melakukan tugas serta fungsinya dengan baik. KAP tersebut diduga melanggar aturan auditor ketika melakukan tugas karena tidak mampu memenuhi program audit yang telah ditetapkan.

Pada peristiwa di atas, seharusnya KAP mampu menyediakan pelayanan audit yang independen terhadap laporan keuangan yang menjadi bagian dari assurance. Namun masih ada KAP terbesar di dunia yang tidak berhasil dalam melakukan auditnya. Kegagalan audit pada umumnya terungkap akibat skandal fraud akuntansi mencuat ke masyarakat atau diungkapkan oleh lembaga Otoritas Jasa Keuangan (OJK) atau kemungkinan terbesar ketika terjadinya kepailitan dan 
krisis keuangan pada perusahaan. Selain itu kegagalan audit yang dilakukan oleh KAP juga dapat disebabkan oleh Akuntan Publik (AP) dan tim auditor yang tidak menerapkan standar sebagaimana mestinya. Hal lain dapat juga dikarenakan analisis risiko yang tidak berjalan mulus sehingga kemungkinan besar untuk terjadinya kegagalan audit.

Kasus tersebut memberikan pemahaman bahwa kualitas audit merupakan salah satu hal penting dari jasa yang dilakukan oleh AP, maka salah saji material yang diakibatkan adanya kelalaian hukum serta peraturan yaitu Standar Profesional Akuntan Publik (SPAP) maupun kode etik profesional akuntan publik harus ditindaklanjuti sesuai dengan aturan yang berlaku guna mempertahankan kualitas audit. Menurut Arens, et al. (2017 hlm 63), Auditor bertanggung jawab guna menentukan apakah ada kesalahan besar pada kemampuan perusahaan guna mempertahankan kontinuitas. Terdapat beberapa faktor yang dapat berpengaruh pada kualitas audit diantaranya ukuran perusahaan, audit tenure, reputasi KAP, time budget pressure dan rotasi KAP.

Penelitian yang dilakukan oleh Ramadhan \& Laksito (2018) menunjukkan bahwa audit tenure tidak memengaruhi kualitas audit, itu dikarenakan periode perikatan audit bukan merupakan ukuran kualitas hasil audit. Lamanya masa perikatan memungkinkan auditor untuk lebih memahami kondisi dan proses bisnis klien sehingga AP dapat mengetahui apabila klien melakukan beberapa hal yang ada kaitannya dengan penyusunan laporan keuangan. Kemampuan auditor dapat menjadi tolak ukur dalam mendeteksi kesalahan material baik yang tidak disengaja maupun yang disengaja. Selain itu independensi auditor juga dapat menjadi tolak ukur apakah auditor dapat mengungkapkan kesalahan tersebut atau justru sebaliknya. Namun, hasil tersebut berbeda dengan penelitian oleh Adekunle Abdul-Rahman et al. (2017), menerangkan bahwa audit tenure memengaruhi kualitas audit, karena semakin lamanya keterlibatan auditor dengan klien, namun tidak melewati batas waktu pengaturan yang ditetapkan oleh pemerintah, tidak akan memengaruhi kualitas audit. Masa perikatan auditor tidak dapat menjamin bahwa auditor akan bersikap independen dan objektivitas dalam memberikan jasa auditnya.

Pada penelitian sebelumnya yang dilakukan oleh Akbar Taufik (2017) menuturkan bahwa rotasi auditor memiliki pengaruh pada kualitas audit yang mengartikan bahwa apabila terjadi rotasi auditor maka diharapkan hasil auditnya lebih berkualitas jika auditor sebelumnya juga memberikan kontribusi yang baik dalam melaksanakan pekerjaannya. Sedangkan penelitian Pertamy dan Lestari (2018) menyatakan bahwa rotasi audit tidak memiliki pengaruh dan atau berpengaruh negatif pada kualitas audit. Artinya bahwa semakin sering auditor melaksanakan rotasi audit, hal itu mengakibatkan menurunnya kualitas audit pada suatu perusahaan.

Penelitian yang dilakukan Prasetia \& Rozali (2016) menunjukkan bahwa reputasi KAP memengaruhi kualitas audit, yang artinya reputasi KAP dalam melaksanakan audit memiliki kemampuan jauh lebih baik. Tetapi hasil tersebut tidak serupa dengan penelitian Nugroho (2018) yang mengungkapkan bahwa reputasi KAP tidak memengaruhi kualitas audit, artinya bahwa kualitas audit yang tinggi bukan berarti dari KAP yang terikat oleh KAP big four. Hasil penelitian terdahulu masih menunjukkan adanya kesenjangan hasil yang belum konsisten 
dan adanya kasus-kasus gagal audit yang terus terjadi yang dilakukan oleh KAP ternama ataupun masuk kedalam KAP big four, maka peneliti tertarik guna mengkaji lebih dalam terkait analisis faktor apa saja yang mempunyai dampak atau pengaruh langsung pada kualitas audit. Penelitian ini bertujuan memberikan bukti apakah kualitas audit dipengaruhi oleh faktor-faktor seperti rotasi audit, reputasi KAP dan audit tenure.

\section{TINJAUAN PUSTAKA}

\section{Teori Keagenan}

Teori keagenan diperkenalkan secara luas ke dalam penelitian akuntansi oleh Jensen dan Meckling (1976), yang menjaskan bahwa:

"A contract under which one or more persons (the principals) engage another person (the agent) to perform some service on their behalf which involves delegating some decision making authority to the agent." (1976, hal. 308).

Berdasarkan pemikiran tersebut, bahwa prinsipal dapat melakukan perikatan dengan pihak lain (agen) dalam menunaikan beberapa jasa dengan mengatasnamakan prinsipal melalui pemberian tanggung jawab untuk pengambilan keputusan yang dimilikinya kepada agen tersebut. Terkait dengan teori keagenan, dijelaskan juga adanya asimetri informasi. Asimetri informasi ini muncul akibat dari agen selaku pengelola cenderung lebih mengetahui atas informasi internal dari perusahaan jika dibanding dengan pemegang saham yang merupakan pihak eksternal. Rotasi audit pada dasarnya jika dijalankan sesuai fungsinya, maka dengan adanya rotasi audit akan meningkatkan kualitas audit. Dengan adanya pertukaran auditor diharapkan dapat menjaga independensi, integritas dan kredibilitas dari seorang akuntan publik yang profesional dan menjunjung tinggi kode etik saat melaksanakan auditnya. Audit tenure berhubungan dengan independensi seorang auditor, di mana periode auditor pada perusahaan lebih lama dari aturan yang ditentukan, auditor akan memiliki hubungan dekat yang menyebabkan ketergantungan pada kliennya. Ketergantungan ini menyebabkan auditor kehilangan independensi mereka dan mencoba membantu keinginan manajemen dengan harapan tidak putusnya koneksi dengan klien. Hubungan antara teori keagenan dengan reputasi KAP yaitu reputasi KAP merupakan salah satu faktor penentu berkualitasnya seorang auditor. Hal ini disebabkan oleh persepsi bahwa investor/direktur lebih mampu mempercayai hasil audit KAP terkait dengan KAP big four. Untuk mencegah adanya konflik kepentingan dan asimetri informasi yang tidak diinginkan, maka solusi yang tepat adalah memiliki target untuk sesegera mungkin menyelesaikan proses auditnya dengan tepat waktu.

\section{Rotasi Auditor}

Rotasi audit merupakan sebuah ketetapan yang mengharuskan pergantian akuntan publik di Indonesia sendiri hanya bisa melaksanakan audit atas laporan keuangan perusahaan dengan kurun waktu maksimal 3 tahun secara berturutturut. Para akademisi dan profesi akuntan telah menganjurkan bahwa rotasi auditor dapat membantu dalam mempertahankan independensi, objektivitas dan skeptisisme profesional auditor (Mautz dan Sharaf 1961). Berdasarkan Keputusan 
Menteri Keuangan nomor: 17/KMK.01/2008 tentang “Jasa Akuntan Publik" pasal 3 menyimpulkan bahwa rotasi di Indonesia bersifat mandatory. Peraturan tersebut mewajibkan pemberian jasa audit umum terhadap laporan keuangan dari perusahaan yang dilakukan oleh seorang AP waktu paling lama 3 (tiga) tahun buku berturut-turut dan oleh KAP kurun waktu paling lama yaitu 6 (enam) tahun buku berturut-turut. Rotasi audit yang dilaksanakan memiliki tujuan utama yaitu guna meningkatkan kualitas audit. Penerapan kewajiban atas pergantian auditor yang berlaku di Indonesia ini telah mendorong para peneliti untuk melakukan penelitian yang difokuskan terhadap isu terkait pergantian auditor ataupun KAP berdasarkan data di Indonesia, misalnya penelitian Pertamy dan Lestari (2018). Begitupun jika rotasi audit diabaikan dan tidak dijalankan maka akan menimbulkan penurunan dari berkualitasnya hasil audit.

Kewajiban rotasi jika dilihat dari pandangan teori agensi yang mana teori ini memberikan gambaran keberadaan perusahaan. Di mana pihak perusahaan lebih baik melaksanakan rotasi audit partner, sesuai regulasi yang berlaku. Karena jika rotasi auditor dilakukan mengikuti regulasi mandatory, maka sikap independensi dalam menjalankan auditnya lebih terjaga yang akan memberikan dampak positif terhadap hasil auditnya yang dikeluarkan dalam bentuk opini. Sebaliknya jika rotasi auditor tidak dilakukan, maka kemungkinan besarnya akan berdampak negatif terhadap hasil auditnya karena sangat dimungkinkan terjadinya penyebab yang dapat mengganggu sikap independensi misalnya adanya kedekatan hubungan antara AP dengan klien dan adanya konflik kepentingan yang bisa saja mengganggu sikap independensi dari seorang auditor. Hal tersebut dapat mengganggu auditor dalam memberikan hasil opininya. Menurut penelitian Akbar Taufik (2017) menilai bahwa rotasi auditor memiliki pengaruh pada kualitas audit, namun penelitian Pertamy dan Lestari (2018) menjelaskan bahwa rotasi audit tidak memiliki pengaruh dan atau berpengaruh negatif pada kualitas audit. Maka dari itu hipotesis yang dibangun pada penelitian ini yaitu:

\section{H1: Rotasi Auditor berpengaruh terhadap Kualitas Audit.}

\section{Audit Tenure}

Audit tenure ialah kurun waktu untuk ikatan audit antara klien dan KAP sehubungan dengan layanan audit yang diterima. Penelitian ini mengasumsikan bahwa mandat audit terkait dengan independensi auditor, tenure panjang yang telah melampaui batas peraturan yang ditetapkan oleh pemerintah antara auditor dan kliennya akan menciptakan kedekatan yang sangat berpengaruh dengan independensi auditor (Nurintiati \& Purwanto, 2017). Dalam penelitian Nugroho (2018) yang mengambil perusahaan manufaktur dalam sampel penelitiannya menjelaskan bagaimana dampak dari audit tenure pada kualitas audit. Kesimpulan studi tersebut menjelaskan bahwa audit tenure memengaruhi kualitas audit. Itu berarti semakin lama masa perikatan KAP dengan klien namun tidak melewati masa regulasi yang telah ditetapkan oleh pemerintah maka hal tersebut dianggap akan memengaruhi kualitas audit. Jika periode penunjukan audit melebihi batas peraturan, ini akan menyebabkan hubungan yang erat antara auditor dengan kliennya untuk mengurangi sikap objektivitas dan independensi auditor merasa takut untuk mengungkapkan keadaan bisnis klien. Objektivitas layanan audit sangat penting dan dapat menimbulkan ancaman ketika klien memegang janji 
jangka panjang dengan auditor yang bersangkutan. Pernyataan ini didukung oleh penelitian Nurintiati \& Purwanto (2017), Paramita \& Latrini (2015), dan Pramaswaradana et al. (2017).

Untuk menguji efek dari audit tenure pada kualitas audit, peneliti menduga bahwa semakin lama masa klien dengan auditor, dengan catatan tidak melebihi regulasi yang berlaku, maka hal tersebut dirasa semakin mudah dalam memahami proses bisnis klien sehingga prosedur audit yang disusun dapat dijalankan dengan baik sesuai kode etik profesi akuntan publik. Selain itu peneliti juga berpendapat bahwa auditor akan lebih memahami pengukuran dan pengakuan aset perusahaan yang disajikan dalam laporan keuangan sesuai standar akuntansi keuangan. Hal tersebut menjadi salah satu kemudahan bagi auditor dalam proses inspeksi untuk meningkatkan kualitas audit yang diberikan. Karena apabila masa penunjukan audit hanya berlangsung selama satu tahun, akan terlihat bahwa auditor tidak tahu bagaimana kondisi perusahaan secara mendalam. Penelitian yang dilakukan Ramadhan \& Laksito (2018) menerangkan bahwa audit tenure tidak memengaruhi kualitas audit, namun penelitian oleh Adekunle Abdul-Rahman et al. (2017), yang menunjukkan bahwa audit tenure memengaruhi kualitas audit. Sehingga hipotesis yang dibangun pada penelitian ini yaitu:

\section{H2: Audit Tenure berpengaruh terhadap Kualitas Audit.}

\section{Reputasi KAP}

Reputasi KAP ialah kinerja dan rasa percaya publik yang diberikan auditor atas nama auditornya Nizar (2017). KAP dapat dibagi menjadi dua kelompok utama: big four auditor sebagai sebuah kelompok perusahan audit yang tergolong besar dan non-big four sebagai sebuah kelompok perusahaan audit yang tergolong kecil. Auditor big four menuturkan bisa memberi "audit kualitas yang lebih baik" dari auditor non-big four (Ramadhan \& Laksito, 2018). Berdasarkan teori keagenan, reputasi KAP menjadi salah satu faktor penentu berkualitasnya seorang auditor. Hal ini disebabkan oleh pemikiran bahwa klien/direktur lebih yakin atas hasil audit yang dilakukan oleh auditor KAP, terkait KAP yang tergolong pada big four, yang juga mengakibatkan manajemen tidak menggantikan KAP. Dalam penelitian yang dilakukan oleh Ramadhan \& Laksito (2018) menjelaskan reputasi KAP berpengaruh pada kualitas audit. KAP yang bereputasi menghasilkan "kualitas audit yang tinggi karena mereka dapat memastikan" bahwa klien mereka membuat informasi yang berkualitas baik. Hasil penelitian ini mengatakan reputasi KAP ini mempunyai dampak signifikan pada kualitas audit. Pernyataan ini didukung oleh peneliti Fauzan Prasetia \& Yuniarti Rozali (2016), Permatasari \& Astuti (2018) dan Pham et al. (2017). Namun penelitian yang dilakukan oleh Nugroho (2018) yang menyatakan reputasi KAP tidak memengaruhi kualitas audit, artinya hal ini menunjukkan bahwa kualitas audit yang baik tidak mesti harus bersumber dari KAP yang terikat oleh KAP big four. Maka hipotesis yang dibangun pada penelitian ini yaitu:

H3: Reputasi KAP berpengaruh terhadap Kualitas Audit. 
Gambar 1. Model Penelitian

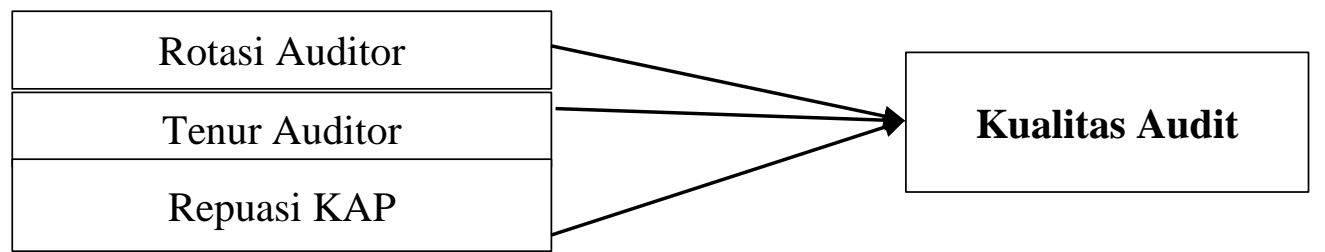

Sumber: Data Diolah Peneliti (2021)

\section{METODOLOGI PENELITIAN}

Jenis penelitian menurut data yang digunakan kali ini ialah data kuantitatif yaitu data yang ditampilkan dalam bentuk angka dari suatu pengukuran, membilang, serta observasi yang dapat dianalisis dengan menggunakan metode statistik, untuk mendapatkan kecenderungan, komparasi hasil melalui perbandingan kelompok, prediksi hubungan antar variabel, sehingga dapat disajikan dalam format data-data statistik (Riadi, 2016:48).

\section{Sumber Data}

Data yang dipilih bersumber dari data sekunder yaitu laporan keuangan tahunan perusahaan manufaktur yang terdaftar di Bursa Efek Indonesia (BEI) tahun 2016-2018 pada sektor barang konsumsi yang telah diaudit dan dipublikasikan. Peneliti mengambil sampel perusahaan manufaktur karena kasus gagal audit sedang marak terjadi pada sektor tersebut, sehingga hal ini mendukung untuk menjadi dasar pengambilan sampel. Data penelitian tersebut diperoleh secara langsung dari BEI, www.idx.co.id, dan situs resmi yang mempublikasikan laporan keuangan tahunan perusahaan dengan kriteria sampel ditunjukkan pada Tabel 1.

Tabel 1. Kriteria Pemilihan Sampel

\begin{tabular}{clc}
\hline No & \multicolumn{1}{c}{ Kriteria Sampel Penelitian } & Jumlah \\
\hline \multirow{2}{*}{1} & $\begin{array}{l}\text { Perusahaan manufaktur yang terdaftar di Bursa Efek Indonesia } \\
\text { pada tahun pelaporan 2016 - 2018 }\end{array}$ & 194 \\
2 & $\begin{array}{l}\text { Perusahaan bukan merupakan sektor industri barang konsumsi } \\
3\end{array}$ & $\begin{array}{l}\text { Perusahaan tidak berturut - turut melaporkan annual report pada } \\
\text { tahun pelaporan 2016 -2018 }\end{array}$ \\
& Perusahaan tidak menyajikan data yang dibutuhkan pada penelitian & $(6)$ \\
ini & $(6)$ \\
& Total perusahaan yang menjadi sampel & 63 \\
& Jumlah periode obervasi & 3 \\
& Total sampel penelitian & $\mathbf{1 8 9}$ \\
\hline
\end{tabular}

Sumber: Data Diolah Penelitia (2020)

Hasil proses pemilihan sampel menggunakan kriteria purposive sampling, memberikan sampel terpilih dengan jumlah 189 perusahaan. 


\section{Kualitas Audit}

Kualitas audit yaitu semua hal yang terjadi ketika auditor melaksanakan audit atas laporan keuangan, dapat mendeteksi penyimpangan pada sistem pencatatan akuntansi klien dan melaporkan dalam bentuk laporan keuangan yang diaudit, di mana laporan tersebut akan dipandu berdasarkan standar audit dan kode etik akuntan yang berlaku guna memastikan opininya terhadap kewajaran laporan keuangan yang telah disusun oleh manajemen perusahaan dalam bentuk laporan kualitas audit dengan tetap menjaga karakteristik dari kualitas audit (Nugroho, 2018).

Tabel 2. Pengukuran Variabel

\begin{tabular}{llll}
\hline \multirow{2}{*}{$\begin{array}{l}\text { Kualitas } \\
\text { Audit }\end{array}$} & Nilai 1 & $\begin{array}{l}\text { Diberikan ketika badan usaha memperoleh opini } \\
\text { WTP }\end{array}$ & Skala \\
\cline { 2 - 4 } $\begin{array}{l}\text { Rotasi } \\
\text { Auditor }\end{array}$ & Score 1 & $\begin{array}{l}\text { Terjadi rotasi auditor } \\
\text { WTP }\end{array}$ & Nominal \\
\hline Score 0 & Tidak terjadi rotasi auditor & Nominal \\
$\begin{array}{l}\text { Audit } \\
\text { Tenure }\end{array}$ & Nilai 2 & $\begin{array}{l}\text { Panjang masa perikatan audit antar Auditor dan } \\
\text { auditee apabila telah berjalan selama 1 tahun } \\
\text { Panjang masa perikatan audit antar Auditor dan } \\
\text { auditee apabila telah berjalan selama 2 tahun } \\
\text { Panjang masa perikatan audit antar Auditor dan } \\
\text { auditee apabila telah berjalan selama 3 tahun } \\
\text { Panjang masa perikatan audit antar Auditor dan } \\
\text { auditee apabila telah berjalan selama 4 tahun }\end{array}$ & Interval \\
\hline $\begin{array}{l}\text { Reputasi } \\
\text { KAP }\end{array}$ & Nilai 1 & $\begin{array}{l}\text { Diberikan ketika badan usaha di audit dengan KAP } \\
\text { Big Four } \\
\text { Diberikan ketika badan usaha di audit dengan KAP } \\
\text { non-Big Four }\end{array}$ & Nominal \\
\hline
\end{tabular}

Sumber: Data Diolah Penelitia (2020)

\section{Audit Tenure}

Audit tenure merupakan periode untuk hubungan audit yang melibatkan KAP dan klien dalam kaitannya dengan layanan audit yang diterima (Nurintiati \& Purwanto, 2017).

\section{Rotasi Audit}

Rotasi audit merupakan ketetapan yang dilaksanakan perusahaan saat melakukan pergantian KAP sesuai dengan Peraturan Menteri Keuangan No.17 tahun 2008 tentang "Jasa Akuntan Publik", KAP hanya diperbolehkan melakukan audit klien yang sama dalam kurun waktu lima tahun berturut-turut dan tiga tahun berturut-turut bagi AP (Pertamy dan Lestari 2018).

\section{Reputasi KAP}

Reputasi KAP adalah kinerja publik dan kepercayaan yang dipegang oleh auditor atas nama KAP tempat auditor bekerja. Pelanggan biasanya melihat bahwa auditor berasal dari KAP besar dan dikaitkan dengan KAP internasional 
berkualitas lebih tinggi karena auditor memiliki kualitas terkait kualitas, seperti pelatihan, pengakuan internasional, dan keberadaan tinjauan sejawat (Ramadhan \& Laksito, 2018).

\section{Teknik Analisis Data dan Uji Hipotesis}

Dalam melaksanakan analisis dan uji hipotesis, prosedur menggunakan alat bantu program komputer yaitu Statistical Product and Service Solution 26 (SPSS 26) dan Microsoft Excel. Pengujian hipotesis yang diterapkan pada penelitian yaitu Analisis Regresi Logistik dengan Rumus 1.

Rumus 1. Model Regresi Logistik Penelitian

$$
\operatorname{Ln} \frac{\mathrm{p}}{(1-\mathrm{p})}=\alpha+\beta 1 \text { ROTAU }+\beta 2 \text { AUDTE }+\beta 3 \text { REPKAP }+\mathrm{e}
$$

$\begin{array}{ll}\operatorname{Ln} \frac{\mathrm{p}}{(1-\mathrm{p})} & : \text { Kualitas Audit } \\ \alpha & : \text { Konstanta } \\ \text { ROTAU } & : \text { Rotasi Auditor } \\ \text { AUDTE } & : \text { Audit Tenur } \\ \text { REPKAP } & : \text { Reputasi KAP } \\ \mathrm{e} & : \text { Error }\end{array}$

\section{HASIL DAN PEMBAHASAN}

Tabel 3 menunjukkan analisis statistic deskriptif. Nilai minimum dari rotasi auditor yaitu 0 menunjukkan terdapat perusahaan yang tidak melakukan rotasi auditor selama durasi waktu penelitian. Kemudian nilai maksimum dari rotasi auditor yaitu 1 menunjukkan bahwa beberapa perusahaan menerapkan rotasi auditor selama kurun waktu penelitian. Rata-rata (mean) rotasi auditor adalah sebesar 0,063 yang artinya rata-rata rotasi auditor yang dilakukan oleh perusahaan di dalam penelitian adalah 0,063 kali (nilai mendekati 0) atau jarang dilakukan.

Tabel 3. Analisis Statistik Deskriptif

\begin{tabular}{|c|c|c|c|c|c|}
\hline & $\mathbf{N}$ & Minimum & Maximum & Mean & Std. Deviation \\
\hline Rotasi Audit & 189 & 0,00000 & 1,00000 & 0,06 & 0,24 \\
\hline Audit Tenure & 189 & 1,00000 & 3,00000 & 1,89 & 0,82 \\
\hline Reputasi KAP & 189 & 0,00000 & 1,00000 & 0,42 & 0,49 \\
\hline Kualitas Audit & 189 & 0,00000 & 1,00000 & 0,71 & 0,45 \\
\hline $\begin{array}{l}\text { Valid N } \\
\text { (listwise) }\end{array}$ & 189 & & & & \\
\hline
\end{tabular}

Sumber: hasil ouput IBM SPSS 26 (2020)

Nilai minimum audit tenure yang menunjukkan lama tahun perikatan antara auditor dengan auditee adalah 1, yang berarti ada perusahaan di dalam penelitian yang memiliki lama tahun perikatan dengan auditor selama satu tahun. Nilai maksimum audit tenure yang menunjukkan lama tahun perikatan antara auditor dengan auditee adalah 3, artinya ada perusahaan di dalam 
penelitian yang memiliki lama tahun perikatan dengan auditor selama tiga tahun. Perusahaan yang memiliki data audit tenure terlama di dalam penelitian karena mendapatkan nilai tertinggi yaitu sebesar 3 adalah sebanyak 55 perusahaan dari total 189 perusahaan. Nilai tersebut menunjukkan bahwa berdasarkan perusahaan yang terpilih menjadi sampel, sebagian besar memiliki jangka waktu perikatan minimal 3 tahun.

Nilai minimum untuk variabel reputasi KAP yaitu 0 menunjukkan bahwa terdapat perusahaan yang diaudit oleh KAP non-Big Four. Kemudian nilai maksimum dari variabel reputasi KAP yaitu 1 yang menunjukkan bahwa terdapat perusahaan yang diaudit oleh KAP Big Four. Rata-rata (mean) variabel reputasi KAP adalah sebesar 0,42 yang artinya rata-rata perusahaan yang memakai jasa KAP Big Four adalah sebanyak 0,42 dari total penelitian atau lebih kecil dari total penelitian. Sedangkan standar deviasi rotasi audit adalah sebesar 0,49 . Nilai ratarata (mean) yang lebih kecil dari standar deviasi yaitu $0,42<0,49$. Nilai rata rata tersebut diartikan bahwa tingkat penyebaran perusahaan yang memakai jasa KAP Big Four masih rendah.

Nilai kualitas audit minimum adalah 0 , yang mengartikan perusahaan tidak menerima pendapat WTP atau perusahaan menerima pendapat lain selain WTP dari KAP. Nilai kualitas audit maksimum adalah 1, yang artinya bahwa perusahaan menerima pendapat WTP. Nilai tersebut menunjukkan bahwa dari perusahaan yang menjadi sampel, ada yang menerima opini WTP dan juga opini selain WTP. Data sampel yang mendapat opini WTP sebesar 50 perusahaan, sedangkan hanya 25 data perusahaan yang tidak mendapat opini WTP. Rata rata (mean) kualitas audit sebesar 0,71. Sedangkan standar deviasi kualitas audit sebesar 0,45. Nilai rata rata (mean) lebih besar dari standar deviasi $0,71>0,45$. Nilai rata-rata tersebut diartikan bahwa tingkat ukuran penyebaran data variabel kualitas audit tinggi.

Hasil pengujian kelayakan model menunjukkan nilai Chi Square tabel untuk DF 5 pada taraf signifikansi 0,05 adalah sebesar 0,744. Karena nilai Chi Square Hosmer and Lemeshow hitung 0,744 < Chi Square table 11,070 atau nilai signifikansi sebesar 0,98 $(>0,05)$. Berdasarkan hasil ini, bisa disimpulkan bahwa model regresi cocok untuk analisis lebih lanjut, model ini mampu memprediksi data pengamatan karena tidak adanya pembeda antara klasifikasi yang diprediksi dan klasifikasi yang diamati dari model yang dikatakan sesuai.

Berdasarkan hasil pengujian keseluruah model ditemukan bahwa nilai -2 Log Likelihood awal adalah 226.146. Sesudah variabel independen dimasukkan pada model regresi, maka nilai -2 Log Likelihood akhir adalah sebesar 211.089. Sesuai output tersebut terdapat penurunan nilai -2 Log Likelihood sebesar 15.057. Artinya bahwa menambahkan dengan variabel independen ke model dapat meningkatkan kecocokan keseluruhan model dan menunjukkan model regresi yang baik. 
Tabel 4. Hasil Model Regresi

Variables in the Equation

\begin{tabular}{ccccccc}
\hline & B & S.E. & Wald & df & Sig. & Exp(B) \\
\hline Step Rotasi Audit & $-1,47$ & 0,671 & 4,795 & 1 & 0,029 & 0,23 \\
$1^{\text {a }}$ Audit Tenure & 0,1 & 0,214 & 0,22 & 1 & 0,639 & 1,105 \\
Reputasi KAP & 0,909 & 0,361 & 6,323 & 1 & 0,012 & 2,481 \\
Constant & 0,502 & 0,459 & 1,195 & 1 & 0,274 & 1,652 \\
\hline
\end{tabular}

Sumber: hasil ouput IBM SPSS 26 (2020)

Tabel di atas menerangkan hasil dari uji parsial dengan analisis Regresi Logistik. Berdasar pada model regresi yang dibentuk, didapat hubungan antar setiap variabel independen yaitu rotasi audit, audit tenure, dan reputasi KAP sebagai variabel independen kualitas audit sebagai variabel dependen yang dapat dijelaskan dengan nilai Exp (B) dan B

Berdasarkan persamaan model regresi logistik di atas menjabarkan bahwa nilai konstanta positif sebesar 0,52 dan nilai Exp (B) sebesar 1,652 memiliki pengertian bahwa peluang perusahaan mendapatkan opini WTP dengan menghasilkan kualitas audit yang baik adalah 0,52 dibandingkan dengan kemungkinan bahwa perusahaan tidak menerima audit berkualitas dengan asumsi semua variabel independen bernilai konstan.

Variabel rotasi auditor mempunyai nilai koefisien negatif senilai 1,47 dan Exp (B) 0,23 yang berarti bahwa jika perubahan/ rotasi auditor meningkat satu satuan, maka probabilitas bahwa perusahaan akan menerima audit berkualitas turun sebesar 1,47 dengan asumsi variabel independen lainnya dianggap konstan. Nilai koefisien negatif berarti bahwa ada hubungan negatif antara rotasi auditor dan kualitas audit. Variabel audit tenure mempunyai nilai koefisien B 0,1 dan Exp (B) 1,105, yang berarti bahwa jika lama tahun perikatan antara auditor dengan auditee meningkat satu satuan, probabilitas bahwa perusahaan akan menerima audit berkualitas naik sebesar 1,105, jika variabel independen lainnya dianggap konstan. Nilai koefisien positif berarti terjadi hubungan positif antara audit tenure dan kualitas audit. Variabel reputasi KAP mempunyai nilai koefisien B 0,909 dan Exp (B) 2,481 yang artinya apabila variabel reputasi KAP mengalami peningkatan satu satuan, maka perusahaan berpeluang untuk memperoleh audit berkualitas naik sebesar 2,481 dengan asumsi variabel independen lainnya dianggap konstan. Nilai koefisien positif memiliki arti bahwa ada hubungan positif antara reputasi KAP dan kualitas audit.

\section{Pengaruh Rotasi Auditor terhadap Kualitas Audit}

Hipotesis pertama (H1) yang dikembangkan pada studi ini membuktikan bahwa rotasi auditor memengaruhi kualitas audit. Analisis menunjukkan bahwa arah negatif dengan sig 0,029 $<0,05$. Berdasarkan hasil analisis di atas, $\mathrm{H}_{0}$ tidak dapat diterima, karena hasil diperoleh dalam penelitian ini menjelaskan bahwa rotasi auditor mempunyai pengaruh negatif yang signifikan pada kualitas audit. Pada praktiknya terdapat peraturan akan pembatasan dalam melakukan jasa asuransi pada klien akan memicu sikap tricky oleh partner untuk bertukar bendera satu sama lain. Oleh sebab itu rotasi seolah hanya formalitas dalam menunaikan kewajiban dalam memberikan jasa asuransi pada klien, dan tidak untuk 
meningkatkan atau mempertahankan kualitas dari jasa yang diberikan.

Berdasarkan data diketahui bahwa rotasi auditor memengaruhi kualitas audit secara negatif. Pada hasil menunjukkan bahwa dari 189 sampel perusahaan, hanya ada 12 sampel perusahaan yang melakukan rotasi auditor selama kurun waktu penelitian. Perusahaan yang melakukan rotasi auditor adalah PT ALTO, PT BTEK, PT DPUM, PT GZCO, PT IIKP, PT JPFA, PT LMPI, PT MRAT, PT SIDO. Hasil ini selaras dengan penelitiannya Andriani dan Nursiam (2017) yaitu menerangkan bahwa dengan menjalankan rotasi audit bukanlah jaminan untuk memberikan hasil audit berkualitas. Salah satu penyebab temuan tersebut adalah karena saat dilakukannya pergantian auditor, maka auditor baru mempunyai kemungkinan belum menguasai bidang bisnis perusahaan tersebut atau belum memiliki pengetahuan yang cukup sehingga belum mampu menghasilkan keputusan audit yang tepat dan menjadi kurang berkualitas.

Maka dapat disimpulkan bahwa teori yang dibangun dapat mendukung hasil penelitian yaitu dengan adanya rotasi auditor dapat memberikan dampak yang signifikan atas kualitas dari hasil audit, namun signifikasinya bernilai negatif. Hasil ini serupa dengan penelitian Akbar Taufik (2017) yaitu rotasi auditor memiliki pengaruh pada kualitas audit. Rotasi audit dilaksanakan dengan tujuan mengurangi hubungan antara klien dengan auditor yang terlalu dekat sehingga mampu menurunkan kualitas audit yang diperoleh. Menurut Kurniasih (2014), auditor mengambil peran selaku pihak eksternal yang bersifat independen dan mengemban tugas dalam memberi penilaian kewajaran terhadap penyajian laporan keuangan dengan dibuktikan dari hasil audit yang memiliki kualitas.

\section{Pengaruh Audit Tenure terhadap Kualitas Audit}

Hipotesis kedua (H2) yang diuji pada penelitian ini menunjukkan bahwa variabel audit tenure yang menunjukkan jangka waktu perikatan auditor dengan auditee tidak memengaruhi secara signifikan terhadap kualitas audit. Analisis menunjukkan hubungan yang positif dengan signifikansi sebesar 0,639>0,05. Berdasarkan hasil analisis, $\mathrm{H}_{2}$ ditolak dan $\mathrm{H}_{0}$ diterima. Hasil ini menjelaskan bahwa audit tenure tidak berpengaruh signifikan pada berkualitasnya suatu hasil audit. Berdasarkan teori keagenan, auditor independen dibutuhkan sebagai perantara hubungan principal (pemegang saham) dan agen (manajemen).

Auditor yang independen, profesional, dan kompeten sangat dibutuhkan di dalam kinerjanya untuk memberikan audit yang berkualitas baik atas laporan keuangan yang tersedia sehingga laporan keuangan tersebut dapat diandalkan untuk meyakinkan investor dan pemegang saham. Untuk menjaga independensi seorang auditor, maka diberlakukanlah aturan yang menentukan batas waktu perikatan kerja antara auditee dengan auditor yang dikenal sebagai audit tenure. Dengan diterapkannya audit tenure, diasumsikan kualitas audit bisa lebih baik karena perikatan dengan auditee pada periode sebelumnya bisa membuat auditor lebih mudah untuk memahami pencatatan yang dibuat oleh klien. Hal tersebut bisa membantu proses audit yang dapat meningkatkan kualitas audit. Namun, aturan mengenai jangka waktu juga diberlakukan untuk menjaga independensi dari auditor.

Dengan adanya pembatasan jangka perikatan audit akan mengurangi risiko terjadinya penyimpangan yang akan membuat auditor tersebut memiliki 
hubungan yang erat yang menimbulkan tingkatkan kepercayaan auditor pada kliennya. Namun ketergantungan ini juga dapat menimbulkan auditor kehilangan independensi, mencoba membantu keinginan dari manajemen yang berharap bahwa hubungan dengan klien tidak akan terputus, dapat mengurangi rasa objektivitas auditor dan takut akan keadaan saat ini dari bisnis yang sangat publik. Data pada penelitian ini menerangkan bahwa dari 189 sampel perusahaan, di mana perusahaan dengan data audit tenure terlama di dalam penelitian karena mendapatkan nilai tertinggi yaitu sebesar 3 adalah sebanyak 55 perusahaan dari total 75 perusahaan. Nilai tersebut menunjukkan bahwa dari perusahaan yang digunakan dalam sampel, sebagian besar perusahaan memiliki jangka waktu perikatan minimal 3 tahun. Terdapat 44 sampel perusahaan yang menerima opini WTP yang masa perikatan auditor eksternalnya bervariasi. Pada PT ALTO, PT MRAT, dan PT SIDO melakukan perikatan audit dengan auditor yang sama selama 2 tahun berturut-turut dan menerima opini wajar tanpa pengecualian. Sedangkan 41 perusahaan seperti PT ADES, PT BRNA, PT BUDI, PT BWPT, PT CEKA, dan lainlain yang melakukan perikatan audit dengan auditor selama dalam jangka waktu minimal 3 tahun berturut-turut dan menerima opini wajar tanpa pengecualian pada kurun waktu 2016-2018. Terdapat perusahaan yang menjalin perikatan audit dengan auditornya selama 2 dan 3 tahun yaitu PT GZCO, PT IIKP, PT JPFA, dan PT LMPI yang dalam laporan keuangannya tidak menerima opini WTP.

Berdasarkan data di dalam penelitian ini, hipotesis kedua ditolak. Beberapa faktor penyebabnya bisa dikarenakan masa perikatan audit yang baru berjalan 1 tahun sehingga auditor belum mengetahui bagaimana pencatatan akuntansi yang dilakukan oleh klien, auditor dapat memberi pendapat yang salah atau tidak sesuai dengan sesungguhnya dan tidak berani mengungkapkan jika terjadi penyimpangan. Hasil penelitian ini serupa pada penelitian Ramadhan \& Laksito (2018) yang menunjukkan bahwa audit tenure tidak memengaruhi kualitas audit, karena periode perikatan audit bukan merupakan ukuran kualitas hasil audit. Lamanya masa perikatan memungkinkan auditor untuk lebih memahami kondisi dan proses bisnis klien sehingga AP dapat mengetahui apabila klien melakukan hal-hal yang ada kaitannya dengan penyajian laporan keuangan. Penelitian Andriani dan Nursiam (2017) juga mengungkapkan bahwa audit tenure tidak berpengaruh pada kualitas audit yang dimana masa perikatan audit tidak menjadi tolak ukur berkualitasnya hasil audit.

\section{Pengaruh Reputasi KAP terhadap Kualitas Audit}

Hipotesis ketiga $\left(\mathrm{H}_{3}\right)$ yang diuji pada studi ini menyimpulkan bahwa reputasi KAP Big Four berpengaruh signifikan positif terhadap kualitas audit. Analisis menunjukkan bahwa arah koefisien positif dengan tingkat penglihatan dengan hasil 0,012<0,05. Berdasarkan hasil analisis, hipotesis ketiga diterima itu berarti reputasi KAP memiliki dampak positif yang signifikan pada kualitas audit. Hasil tersebut mendukung adanya teori agensi karena reputasi KAP dapat menjadi salah satu penentu kualitas auditor. Publik memiliki persepsi bahwa hasil audit yang diberikan oleh auditor yang menjadi anggota KAP terkait dengan KAP big four lebih mampu dipercaya dan manajemen perusahaan tetap dapat dipercaya.

KAP big four juga dikenal dalam pelaksanaan auditnya dengan baik karena sesuai dengan standar sehingga dianggap lebih dapat mampu menemukan 
kesalahan dan kecurangan dalam laporan keuangan bisnis dan bisa mematuhi peraturan serta hukum yang berlaku. KAP terkait dengan KAP big four mengungguli KAP non-big four dalam hal reputasi, teknologi audit dan sumber daya, serta jumlah klien yang dapat memberikan dorongan pada auditor untuk melakukan audit secara profesional. Berdasarkan 189 sampel perusahaan di dalam penelitian ini, terdapat 80 sampel yang menggunakan layanan KAP big four, sementara 109 sampel memakai layanan KAP non-big four. Perusahaan yang memakai layanan KAP big four yaitu PT BWPT, PT CEKA, PT DLTA, PT DPUM, PT DSNG, PT DVLA, PT FAST, PT GGRM, PT HMSP, PT ICBP, PT INDF, PT KLBF, PT LSIP, PT MERK, PT PSDN, PT RMBA, PT ROTI, PT SGRO, PT SIDO, PT SIMP, PT TCID, PT TOBA, PT TOTO, DAN PT UNVR yang menerima pendapat wajar tanpa pengecualian.

Hasil studi ini sesuai dengan penelitian Pham et al. (2017), Ramadhan \& Laksito (2018), Fauzan Prasetia \& Yuniarti Rozali (2016), Permatasari \& Astuti (2018) yang menyimpulkan bahwa reputasi KAP memiliki dampak positif yang signifikan pada peningkatan kualitas audit laporan keuangan perusahaan. Semakin baik reputasi KAP, maka kualitas audit yang dihasilkan lebih baik pula. KAP yang berafiliasi dengan KAP big four dianggap akan lebih unggul dalam bidang teknologi, sumber daya, dan lebih dikenal oleh masyarakat dalam pelaksanaan auditnya yang sesuai dengan standar yang berlaku. Maka disimpulkan bahwa teori yang dibangun dapat mendukung hasil penelitian dan reputasi KAP bisa menjadi salah satu faktor penentu berkualitasnya seorang auditor. Hal ini dikarenakan persepsi publik lebih yakin terhadap hasil audit yang diterbitkan oleh auditor yang menjadi anggota KAP yang berafiliasi dengan KAP big four.

\section{SIMPULAN}

Hasil studi menunjukkan rotasi auditor memiliki pengaruh negatif yang signifikan pada kualitas audit. Saat dilakukan rotasi auditor, maka kualitas audit dapat menurun secara signifikan karena ada kemungkinan bahwa auditor belum menguasai bidang bisnis perusahaan tersebut atau belum memiliki pengetahuan yang cukup sehingga belum mampu menghasilkan keputusan audit yang tepat dan menjadi kurang berkualitas. Hasil menunjukkan audit tenure tidak terdapat pengaruh signifikan pada kualitas audit. Faktor penyebabnya bisa dikarenakan masa perikatan audit yang baru berjalan 1 tahun membuat auditor belum mengetahui bagaimana pencatatan akuntansi yang dilakukan oleh klien, sehingga auditor dapat memberi pendapat yang salah atau tidak sesuai dengan sesungguhnya ataupun belum berani mengungkapkan jika terjadi penyimpangan karena belum memiliki keyakinan yang cukup. Hasil studi menunjukkan bahwa reputasi KAP memiliki pengaruh positif yang signifikan pada kualitas audit. Hasil ini dapat disebabkan karena publik lebih yakin pada hasil audit yang dibuat oleh auditor yang menjadi anggota KAP yang berafiliasi dengan KAP big four dengan asumsi bahwa KAP big four jauh baik menerapkan standar audit karena didukung sumber daya yang profesional dan independen. 


\section{Keterbatasan Penelitian}

Terbatasnya jumlah sampel pencarian karena ada beberapa perusahaan yang tidak memberikan informasi yang diperlukan untuk penelitian. Studi ini hanya menggunakan perusahaan manufaktur yang terdaftar di BEI pada periode penelitian selama tiga tahun, yaitu tahun 2016-2018.

a. Variabel Kualitas Audit hanya diproksikan dengan opini WTP dan selain WTP.

b. Hasil nilai Nagelkerke $R$ Square sebesar 11\%. Ini berarti bahwa variabel independen pada studi ini hanya mampu menjelaskan variabel dependen sebesar $11 \%$, sedangkan sisanya $89 \%$ dijelaskan oleh variabel lain yang tidak dipakai pada studi ini seperti audit fee, ukuran KAP, client importance, spesialisasi auditor, auditor switching, dan umur publikasi.

\section{Saran}

c. Bagi peneliti maka disarankan agar periode penelitian ditingkatkan untuk menggeneralisasi hasil studi dan penelitian lebih lanjut diharapkan untuk memakai jenis industri multi industri seperti telekomunikasi, pertambangan, perbankan, dll, sehingga dapat membuat perbandingan kualitas audit pada tiap jenis industri atau sektor dan hasilnya dapat digeneralisasikan.

d. Bagi peneliti selanjutnya diharapkan mampu memperluas variabel independen studi dan menambahkan variabel terikat yang mampu memengaruhi kualitas audit untuk memperkuat pengujian.

e. Bagi investor diharapkan dapat memperhatikan tingkat kemampuan perusahaan dalam menyajikan laporan keuangan yang berkualitas pengambilan keputusan dalam berinvestasi agar terhindar dari kesalahan yang merugikan.

\section{DAFTAR PUSTAKA}

Adekunle Abdul-Rahman, O., Olajide Benjamin, A., \& Hakeem Olayinka, O. (2017). Effect of Audit Fees on Audit Quality: Evidence from Cement Manufacturing Companies in Nigeria. In European Journal of Accounting, Auditing and Finance Research.

Akbar Taufik. 2017. Pengaruh Time Budget Pressure, Tenure Audit dan Rotasi Audit Terhadap Kualitas Audit. Profita, Volume 10. No.3 Desember 2017.

Andriani, Ninik dan Nursiam. 2017. Pengaruh Fee Audit, Audit Tenure, Rotasi Auditor dan Reputasi Auditor Terhadap Kualitas Audit. Riset Akuntansi dan Keuangan Indoneisa, 3 https://doi.org/10.23917/reaksi.v3i1.5559

2018.

Arens, A. A. (2014). Auditing and Assurance Service. In Erlangga.

Arens, A. A. (2017). Auditing and Assurance Services An Integrated Approach (16th ed).

Fauzan Prasetia, I., \& Yuniarti Rozali, R. D. (2016). Pengaruh Tenur Audit, Rotasi Audit Dan Reputasi Kap Terhadap Kualitas Audit (Studi Pada Perusahaan Manufaktur Yang Terdaftar Di Bursa Efek Indonesia Tahun 2011-2014). Jurnal ASET (Akuntansi Riset). https://doi.org/10.17509/jaset.v8i1.4020 
Ghozali, I. (2018). Aplikasi Analisis Multivariate dengan Program IBM SPSS 25. (Edisi 9). Semarang: Badan Penerbit Universitas Diponegoro.

Institut Akuntan Publik Indonesia. (2013). Standar Audit 200. https://iapi.or.id/Iapi/detail/362

Institut Akuntan Publik Indonesia. (2013). Standar Audit 700. https://iapi.or.id/Iapi/detail/362

Jensen, M. C. \& Meckling, W. H. 1976. Theory of Firm: Managerial Behavior, Agency Cost and Ownership Structure. Journal of Financial Economics. 3 pp.305360. https://doi.org/10.1016/0304-405X(76)90026-X

Keputusan Menteri Keuangan Republik Indonesia. (2008). Menteri Keuangan Republik Indonesia Nomor: 17/KMK.01 /2008 Tentang Jasa Akuntan Publik.

Kurniasih, Margi dan Abdul Rohman. 2014. Pengaruh Fee Audit, Audit Tenure, dan Rotasi Audit Terhadap Kualitas Audit. Diponegoro Journal of Accounting. Vol.2 No.3:1-10.

Mautz, R.K. dan H.A. Sharaf. 1961. The Philosophy of Auditing. Sarasota, Florida: American Accounting Association.

Nizar, A. A. (2017). Pengaruh Rotasi, Reputasi, dan Spesialisasi Auditor Terhadap Kualitas Audit. Jurnal Ilmiah Akuntansi, 15(2). https://doi.org/10.30595/kompartemen.v15i2.1877

Nugroho, L. (2018). Analisa Faktor-Faktor Yang Mempengaruhi Kualitas Audit (Studi Empiris pada Perusahaan Manufaktur Industri Sektor Barang Konsumsi yang Terdaftar Di Bursa Efek Indonesia tahun 2014-2016). Jurnal Maneksi, 7(1), 55. https://doi.org/10.31959/im.v7i1.89

Nurintiati, A., \& Purwanto, A. (2017). Pengaruh Tenure Kap, Ukuran Kap, Spesialisasi Auditor Dan Audit Fee Terhadap Kualitas Audit Dengan Moderasi Komite Audit. 6(1), 100-112.

Paramita, N., \& Latrini, N. (2015). Pengaruh Ukuran Perusahaan, Umur Publikasi, Masa Perikatan Audit, Pergantian Manajemen Pada Kualitas Audit. E-Jurnal Akuntansi.

Permatasari, I. Y., \& Astuti, C. D. (2018). Pengaruh Fee Audit, Rotasi Auditor , Dan Reputasi. Jurnal Akuntansi Trisakti. https://doi.org/10.25105/jat.v5i1.4839

Pham, N. K., Duong, H. N., Pham, T. Q., \& Ho, N. T. T. (2017). Audit Firm Size, Audit Fee, Audit Reputation and Audit Quality: The Case of Listed Companies in Vietnam. Asian Journal of Finance \& Accounting. https://doi.org/10.5296/ajfa.v9i1.10074

Pramaswaradana, I. G. N. I., Astika, \& Putra, I. B. (2017). Pengaruh Audit Tenure, Audit Fee, Rotasi Auditor, Spesialsiasi Auditor, Dan Umur Publikasi Pada Kualitas Audit. E-Jurnal Akuntansi, 19, 168-194.

RAF., Pertamy \& Tri Lestari. (2018). Pengaruh Audit Tenure, Rotasi Audit Dan Reputasi Kap Terhadap Kualitas Audit (Studi Empiris Pada Perusahaan Manufaktur Sektor Industri Barang Konsumsi Yang Terdaftar Di Bursa Efek Indonesia Periode 2015-2017). p-ISSN: 2548 7078. Vol. 03 No. 02 Oktober 2018. 
Ramadhan, I. N. \&, \& Laksito, H. (2018). Pengaruh Reputasi Kantor Akuntan Publik (Kap), Audit Tenure , Dan Biaya Audit Terhadap Kualitas Audit. Diponegoro Journal Of Accounting.

Riadi, Edi. (2016). Statistika penelitian (analisis manual dan IBM SPSS). Andi Yogyakarta.

Sugiyono. (2016). Metodologi Penelitian Kuantitatif, Kualitatif, dan R\&D. In CV Alfabeta.

Tuanakotta, T. (2015). Audit Kontemporer (International Standards on Auditing). In Salemba Empat. 
EQUITY, Vol. 24, No.1, 2021, 123-140

Halaman ini sengaja dikosongkan

untuk kepentingan penggenapan halaman 